\title{
Cmentarz w miejscowym planie zagospodarowania przestrzennego
}

\section{Anna Wieczorek}

\section{STRESZCZENIE}

Artykuł omawia wybrane problemy związane z wprowadzaniem do miejscowych planów zagospodarowania przestrzennego ustaleń dotyczących cmentarzy, w szczególności postuluje aby:

1) w sposób precyzyjny określić, co należy rozumieć pod pojęciem przeznaczenie terenu;

2) zlikwidować obowiązek ustalania intensywności zabudowy;

3) wprowadzić zasadę, że określanie wysokości zabudowy i linii zabudowy ma charakter fakultatywny.

Na przykładzie cmentarza, artykuł wskazuje na niedostatek precyzji przepisów dotyczących planowania i gospodarowania przestrzenia, wynikający m.in. z braku definicji szeregu określeń oraz różnego definiowania tych samych pojęć w poszczególnych aktach prawa. Omawia sposoby postępowania w sytuacji, kiedy ustawa o planowaniu i zagospodarowaniu przestrzennym nakazuje wprowadzenie do miejscowego planu zagospodarowania przestrzennego ustaleń dotyczących danego zagadnienia, ale nie definiuje pojęć niezbędnych do dokonania ww. ustaleń. Ostrzega, że powyższe sposoby postępowania nie zawsze są respektowane przez organy nadzoru, co prowadzi do stwierdzania nieważności planów miejscowych. Na podstawie przykładowych dokumentów pokazuje, jak do ww. zagadnień odnoszą się osoby mające wpływ na tworzenie prawa.

Sumując, artykuł:

1) uzasadnia potrzebę opracowaniem słownika pojęć stosowanych w planowaniu przestrzennym, budownictwie, geodezji, gospodarce nieruchomościami, ochronie środowiska i zabytków, księgach wieczystych oraz systemie podatkowym, a następnie, na podstawie takiego słownika, dokonywanie zmian poszczególnych aktów prawa;

2) postuluje, aby organy nadzoru szanowały władztwo planistyczne gmin.

Słowa kluczowe: cmentarz, miejscowy plan zagospodarowania przestrzennego, cel publiczny, ustawy, definicje

\section{Wprowadzenie}

Cmentarz to „miasto umarłych” [Krawczuk 1988, s. 3]. Miejsca pochówku zmarłych istniały odkąd istnieje ludzkość. W Polsce, przez wieki, zmarłych chowano na cmentarzach położonych w sąsiedztwie kościołów. Najzamożniejsi i obdarzeni szacunkiem społecznym znajdowali spoczynek w podziemiach świątyń. Cmentarze lokowano w granicach murów obronnych miast. „Poza miastem lokalizowane były tylko dwa typy cmentarzy: choleryczne, zakładane dla ofiar częstych w owych czasach epidemii oraz cmentarze dla osób, którym przepisy kanoniczne odmawiały prawa do spoczynku w poświęconej ziemi. Na takim cmentarzu chowani wiec byli samobójcy, wyklęci, nie ochrzczeni, lichwiarze czy skazani przestępcy, a także ludzie 
wędrownego trybu życia: żebracy, kuglarze, aktorzy" [Grodziska 1988, s. 8]. Można zaryzykować twierdzenie, że w ten sposób rozpoczął się istniejący do dzisiaj podział na cmentarze wyznaniowe i inne.

Pod koniec XVIII w. dostrzeżono konieczność usunięcia cmentarzy z centrów miast. Komisja Policji Obojga Narodów wydała 18 lutego 1792 r. Uniwersał do Miast Wolnych względem cmentarzy i szlachtuzów. „Nakazano w nim magistratom miast, by w porozumieniu z władzami kościelnymi obmyśliły zarówno lokalizację pozamiejskich cmentarzy, jak i niezbędne na ten cel środki" [Grodziska 1988, s. 10]. Na władze miast spadł obowiązek organizowania miejsc chowania zmarłych, co można uznać za początek cmentarzy komunalnych.

W okresie rozbiorów lokalizacje cmentarzy regulowały przepisy państw zaborczych. W 1932 r. weszła w życie ustawa o chowaniu zmarłych i stwierdzaniu przyczyny zgonu (uchz). Z chwilą wejścia w życie ww. ustawy utraciły „moc obowiązującą wszelkie przepisy prawne w sprawach, tą ustawą unormowanych" [art. 18 pkt 2 uchz]. „Zakładanie, rozszerzanie i zamykanie cmentarzy, jako też ich utrzymanie i zarządzanie niemi jest prawem i obowiązkiem gminy, bądź utworzonego w tym celu związku gmin, o ile obowiązek ten dla jednej gminy jest zbyt uciążliwy lub utrudniony" [art. 6 pkt 1 uchz]. Uprawnienia do zakładania, rozszerzania i zamykania cmentarzy „przysługują w ramach obowiązujących przepisów również uznanym przez Państwo związkom religijnym i innym wyznaniowym osobom prawnym i instytucjom wojskowym. Prawa Kościoła Katolickiego do zakładania, rozszerzania, zamykania, jako też zarządzania i utrzymywania swych cmentarzy określa art. XVII Konkordatu, zawartego ze Stolicą Apostolską w dniu 10 lutego 1925 r." [art. 6 pkt 2 uchz]. Ustawa z 1932 r. była zmieniana dwukrotnie, w 1934 r. oraz dekretem z dnia 26.10.1950 r. i obowiązywała do $1958 \mathrm{r}$.

Obecnie, podstawowym aktem prawa, który reguluje kwestie zakładanie i powiększania cmentarzy jest przyjęta w 1958 r. i wielokrotnie nowelizowana ustawa o cmentarzach i chowaniu zmarłych (uc). Zakładanie i rozszerzanie cmentarzy komunalnych należy do zadań własnych gmin, a o zakładaniu cmentarzy wyznaniowych decydują władze kościelne i związki wyznaniowe.

Problematykę zakładania i rozszerzania cmentarzy wyznaniowych reguluje dodatkowo szereg aktów prawa dotyczących stosunku Rzeczypospolitej Polskiej do poszczególnych kościołów i związków wyznaniowych. Szczegółowe omówienie tych zagadnień zawiera książka autorstwa B. Krupy pt. Administracyjnoprawne uwarunkowania inwestycji celu publicznego.

Cmentarz był zawsze tym, co obecnie nazywa się celem publicznym i inwestycją celu publicznego - miejscem publicznie dostępnym, zakładanym i zarządzanym przez władze duchowne, a z czasem również przez władze municypalne. Ustawa o gospodarce nieruchomościami (ugn) stanowi, że celami publicznymi są: "zakładanie i utrzymywanie cmentarzy” [art. 6 pkt 9 ugn], ale nie precyzuje czy chodzi o cmentarze komunalne czy wyznaniowe. Należy przyjąć, że chodzi o obydwa rodzaje cmentarzy. Pogląd ten podziela B. Krupa twierdząc, że każdy „cmentarz (komunalny i wyznaniowy) powinien być uznany za inwestycję celu publicznego (...). Ten brak zróżnicowania dotyczy także rodzaju związku wyznaniowego, który ma budować i zarządzać cmentarzem" [Krupa 2013, s. 114]. 
W rozumieniu ustawy o gospodarce nieruchomościami celami publicznymi są również:

1) „opieka nad nieruchomościami stanowiącymi zabytki w rozumieniu przepisów o ochronie zabytków i opiece nad zabytkami" [art. 6 pkt 5 ugn];

2) „inne cele publiczne określone w odrębnych ustawach” [art. 6 pkt 10 ugn].

Ustawa o ochronie zabytków i opiece nad zabytkami (uz) stanowi, że ochronie oraz opiece podlegają zabytki nieruchome będące cmentarzami, bez względu na ich stan zachowania [art. 6 ust. 1 pkt 1 lit. f uz]. Wiele cmentarzy, w całości lub w części, jest wpisanych do rejestru zabytków lub ewidencji zabytków.

Ustawą o ochronie przyrody (up) wprowadzono ochronę terenów zieleni miast i wsi [art. 2 ust. 1 i ust. 2]. Tereny zieleni, to "tereny urządzone wraz z infrastrukturą techniczną i budynkami funkcjonalnie z nimi związanymi, pokryte roślinnością pełniące funkcje publiczne, a w szczególności parki, zieleńce, promenady, bulwary, ogrody botaniczne, zoologiczne, jordanowskie i zabytkowe, cmentarze, zieleń towarzysząca drogom na terenie zabudowy, placom, zabytkowym fortyfikacjom, budynkom, składowiskom, lotniskom, dworcom kolejowym oraz obiektom przemysłowym” [art. 5 pkt 21 up], czyli „inne cele publiczne określone w odrębnych ustawach" [art. 6 pkt 10 ugn].

To, że cmentarz jest integralnym składnikiem zieleni miejskiej potwierdza rozporządzenie w sprawie wymagań, jakie muszą spełniać cmentarze, groby i inne miejsca pochówku zwłok i szczątków (rozp.g.c), które stanowi, że cmentarze „projektuje się i utrzymuje jako tereny o założeniu parkowym" [§ 3 rozp.g.c]. Traktowanie cmentarzy, jako szczególny rodzaj parków utrwaliło się w świadomości społecznej, w przewodnikach po nekropoliach, w literaturze popularnonaukowej, a nawet w publikacjach naukowych. Za przykład mogą posłużyć publikacje poświęcone cmentarzom A. Długozimy [2009, 2011a, 2011b].

\section{Cmentarz w miejscowym planie zagospodarowania przestrzennego}

\section{Obowiązek sporządzenia miejscowego planu zagospodarowania przestrzennego przy zakładaniu i rozszerzaniu cmentarzy}

Miejscowy plan zagospodarowania przestrzennego, zwany w skrócie planem miejscowym, jest podstawowym narzędziem kształtowania przestrzeni w Polsce, aktem prawa miejscowego w rozumieniu przepisu art. 14 ust. 8 ustawy o planowaniu i zagospodarowaniu przestrzennym (upzp) i źródłem prawa w rozumieniu art. 87 ust. 2 w związku z art. 94 Konstytucji Rzeczypospolitej Polskiej.

Projekt planu miejscowego sporządza wójt, burmistrz albo prezydent miasta, zgodnie z ustawą o planowaniu i zagospodarowaniu przestrzennym oraz z przepisami odrębnymi [art. 15 ust. 1 upzp], a uchwala rada gminy [art. 20 ust. 1 upzp]. Jeżeli wymagają tego przepisy odrębne, to plan miejscowy sporządza się obowiązkowo [art. 14 ust. 7 upzp]. W przypadku zakładania i rozszerzania cmentarzy przepisami odrębnymi nakazującymi sporządzenie ww. planu są:

1) ustawy o cmentarzach i chowaniu zmarłych; 
2) przepisy dotyczące stosunku Rzeczypospolitej Polskiej do poszczególnych kościołów, w szczególności ustawa o stosunku Państwa do Kościoła Katolickiego w Rzeczypospolitej Polskiej (usPKK).

„Cmentarze zakłada się i rozszerza na terenach określonych w miejscowych planach zagospodarowania przestrzennego" [art. 3 uc]. O założeniu lub rozszerzeniu cmentarza komunalnego decyduje rada gminy po uzyskaniu zgody właściwego inspektora sanitarnego [art. 1 ust. 2 uc]. „Właściwe władze kościelne decydują o założeniu lub rozszerzeniu cmentarza wyznaniowego, które może nastąpić na terenie przeznaczonym na ten cel w miejscowym planie zagospodarowania przestrzennego, po uzyskaniu zgody właściwego inspektora sanitarnego" [art. 1 ust. 3 uc].

Ustawa o stosunku Państwa do Kościoła Katolickiego w Rzeczypospolitej Polskiej stanowi, że plany zagospodarowania przestrzennego obejmują inwestycje sakralne i kościelne oraz katolickie cmentarze wyznaniowe. „Przeznaczenie terenu na te cele ustala się w tych planach na wniosek biskupa diecezjalnego lub wyższego przełożonego zakonnego" [art. 42 ust. 1 usPKK]. Grunty będące własnością Skarbu Państwa lub jednostek samorządu terytorialnego, przeznaczone w planach zagospodarowania przestrzennego na ww. cele „będa oddawane w użytkowanie wieczyste albo podlegały sprzedaży kościelnym osobom prawnym na ich wniosek" [art. 42 ust. 2 usPKK]. Inwestycją sakralną ,"jest budowa, rozbudowa, odbudowa kościoła lub kaplicy, a także adaptacja innego budynku na cele sakralne" [art. 41 ust. 2 usPKK]. Inwestycją kościelną jest inwestycja kościelnej osoby prawnej nie wymieniona powyżej [art. 41 ust. 3 usPKK].

W podobny sposób regulują zasady zakładania i rozszerzania cmentarzy inne przepisy dotyczące działających na terenie Polski kościołów. Przykładowo, ustawa o stosunku Państwa do Kościoła Ewangelicko-Augsburskiego w Rzeczypospolitej Polskiej (usPKEA) oraz ustawa o stosunku Państwa do Kościoła Katolickiego Mariawitów w Rzeczypospolitej Polskiej (PKM) stanowią, że grunty będące własnością Skarbu Państwa lub jednostek samorzą$\mathrm{du}$ terytorialnego przeznaczone $\mathrm{w}$ planach zagospodarowania przestrzennego na potrzeby ww. Kościołów, na wniosek władz tych Kościołów będą im oddawane w użytkowanie wieczyste albo sprzedane [art. 27 ust. 1 usPKEA] oraz [art. 19 usPKM].

Procedura sporządzania planu miejscowego jest długotrwała i obarczona ryzykiem naruszenia prawa. Rozpoczyna ją podjęcie przez radę gminy uchwały o przystąpieniu do sporządzania ww. planu. Rada gminy podejmuje uchwałę z własnej inicjatywy lub na wniosek wójta, burmistrza albo prezydenta miasta. Lokalizowanie cmentarzy w planie miejscowym wydaje się szczególnie skomplikowane. Uchwała o przystąpieniu do sporządzania planu miejscowego dotyczącego cmentarza powinna być poprzedzona:

1) uchwałą rady gminy o zamiarze założenia lub rozszerzenia cmentarza komunalnego [art. 1 ust. 2 uc];

2) wnioskiem władz kościelnych, w przypadku założenia lub rozszerzeniu cmentarza wyznaniowego [art. 1 ust. 3 uc], przykładowo wnioskiem biskupa diecezjalnego Kościoła Katolickiego [art. 42 ust. 1 usPKK]. 
Oznacza to, że podjęcie uchwały o przystąpieniu do sporządzania planu miejscowego w celu założenia czy rozszerzenia cmentarza musi być poprzedzone swego rodzaju petycją władz, które ten cmentarz mają tworzyć. Zapewne w powyższej petycji powinien być określony teren przyszłego cmentarza, jeśli przyjąć, że zgoda właściwego inspektora sanitarnego musi być wydana przed podjęciem uchwały o przystąpieniu do sporządzania planu miejscowego.

Nie powinno być kłopotów z wprowadzeniem do ustaleń planu terenu wyznaczonego na cmentarz komunalny - decyduje ta sama rada gminy, zapewne po wcześniej przeprowadzonych konsultacjach społecznych.

W przypadku cmentarzy wyznaniowych konflikt jest możliwy. Przykładowo, teren wyznaczony przez władze kościelne nie uzyskał akceptacji mieszkańców w trakcie wyłożenia projektu planu do publicznego wglądu. Stawia to władze gminy w bardzo trudnej sytuacji. Jak słusznie zauważa B. Krupa „inicjatywa budowy cmentarza wyznaniowego Kościoła Katolickiego może pochodzić wyłącznie od właściwego miejscowo biskupa diecezjalnego lub wyższego przełożonego zakonu. Inicjatywa własna gminy w tym względzie wyłączona jest z mocy art. 42 ust. 1 ustawy z dnia 17 maja 1989 r. , choć gmina nie jest związana wnioskiem w tym względzie, gdyż w ramach przysługującego jej władztwa planistycznego samodzielnie rozstrzyga o przeznaczeniu obszarów gminnych" [Krupa 2013, s. 115]. Powyższa ustawa z dnia 17 maja 1989 r., to ustawa o stosunku Państwa do Kościoła Katolickiego w Rzeczypospolitej Polskiej.

Skoro inicjatywa budowy cmentarza wyznaniowego Kościoła Katolickiego pochodzi wyłącznie od biskupa, to sporządzający plan miejscowy nie może przy powtórnym wyłożeniu do publicznego wglądu projektu planu sam zaproponować terenu na taki cmentarz. Może jedynie nie uwzględnić wniosku władz kościelnych, co zapewne skończy się zaskarżeniem uchwalonego planu.

Zarówno w przypadku cmentarzy komunalnych jak i wyznaniowych, teren przeznaczony na ten cel musi zostać zaakceptowany przez właściwego inspektora sanitarnego [art. 1 ust. 3 uc], tyle, że nie wiadomo czy przed podjęciem uchwały o przystąpieniu do sporządzania planu miejscowego, czy w trakcie sporządzania projektu planu. Niezależnie od wątpliwości natury proceduralnej ustawowy wymóg uzyskania zgody inspektora sanitarnego należy uznać za zasadny. Cmentarz nie powinien wywierać szkodliwego wpływu na otoczenie. Wydane na podstawie ustawy o cmentarzach i chowaniu zmarłych rozporządzenie w sprawie określenia, jakie tereny pod względem sanitarnym są odpowiednie na cmentarze (rozp. san.c) pochodzi z 1959 r., ale zachowało aktualność. Cmentarz powinien być lokalizowany „w izolacji od zabudowań, na gruntach przeznaczonych pod zieleń publiczną lub odpowiednich na jej urządzenie, w pobliżu miejscowej sieci komunikacyjnej” [§ 1 ust. 2 rozp.san.c], „W miarę możności na wzniesieniu” [§ 4 ust. 1 rozp.san.c], a „zwierciadło wody gruntowej powinno znajdować się na głębokości nie wyższej niż 2,5” [§ 4 ust. 2 rozp.san.c]. Rozporządzenie określa odległość cmentarza od budynków mieszkalnych, od zakładów produkujących i przechowujących żywność oraz ujęć wody [§ 3 ust. 1 i ust. 2 rozp.san.c]. 


\section{Władztwo planistyczne gmin a brak definicji w ustawie o planowaniu i zagospodarowaniu przestrzennym}

Uchwalony plan miejscowy - wójt, burmistrz albo prezydent miasta przedstawia wojewodzie „wraz z załącznikami oraz dokumentacją prac planistycznych w celu oceny ich zgodności z przepisami prawnymi” [art. 20 ust. 2 upzp]. „Istotne naruszenie zasad sporządzania (...) planu miejscowego, istotne naruszenie trybu (...) sporządzania, a także naruszenie właściwości organów w tym zakresie, powodują nieważność uchwały rady gminy w całości lub części" [art. 28 ust. 1 upzp]. Z powyższego wyraźnie wynika, że wojewodowie nie mają prawa decydować o przyjętych w planie rozwiązaniach merytorycznych, $\mathrm{w}$ tym o definicjach potrzebnych pojęć.

Plan miejscowy sporządza się w celu „ustalenia przeznaczenia terenów, w tym dla inwestycji celu publicznego, oraz określenia sposobów ich zagospodarowania i zabudowy" [art. 14 ust. 1 upzp]. Zakres stanowienia planu jest bardzo obszerny. W sposób szczegółowy ustalają go przepisy art. 15 ustawy o planowaniu i zagospodarowaniu przestrzennym. W dużym uproszczeniu - w planie miejscowym określa się obowiązkowo:

1) przeznaczenie terenów, czyli czy na danym terenie wolno coś budować, a jeżeli wolno, to jakie obiekty mogą powstać;

2) zasady kształtowania zabudowy, w tym wyrażone takimi wskaźnikami jak: intensywność zabudowy, powierzchnia zabudowy, wysokość zabudowy, linie zabudowy.

Ustawa o planowaniu i zagospodarowaniu przestrzennym i wydane na jej podstawie przepisy wykonawcze nie definiują pojęć: przeznaczenie terenu, powierzchnia zabudowy, wysokość zabudowy, linie zabudowy, a definicja pojęcia intensywność zabudowy nie jest powszechnie zrozumiała.

Rozporządzenie w sprawie „Zasad techniki prawodawczej” (rozp.ztp) stanowi, że w akcie normatywnym:

1) definiuje się dane określenie, jeżeli jest ono wieloznaczne, jest nieostre, albo jego znaczenie nie jest powszechnie zrozumiałe [§ 146 Załącznika do rozp.ztp];

2) można posłużyć się odesłaniami do definicji zawartych $w$ innych aktach prawa [§ 156 Załącznika do rozp. ztp].

W sytuacji braku definicji potrzebnych pojęć sporządzający projekt planu miejscowego może zastosować odesłanie do przepisów odrębnych, jeżeli zawierają odpowiednią definicję i to on dokonuje wyboru, jeśli np. dwa przepisy odrębne różnie definiują to samo pojecie. Jeżeli w przepisach odrębnych nie ma brakującej definicji, sporządzający projekt planu miejscowego może:

1) powołać normę, przy czym stosowanie norm jest dobrowolne;

2) zastosować definicją zaczerpniętą z literatury przedmiotu czy słowników;

3) opracować „własną” definicję, danego określenia.

Z takim rozumowaniem nie zawsze zgadzają się organy nadzoru. Wojewodowie potrafią uznać za istotne naruszenie prawa opracowanie przez sporządzającego plan definicji potrzebnego pojęcia, i co więcej, narzucać definicje uznane przez siebie za właściwe. Tym nie- 
pokojącym incydentom poświecony jest artykuł - Problemy z ocenianiem zgodności z prawem miejscowych planów zagospodarowania przestrzennego: definicje pojęć powierzchnia zabudowy i powierzchnia całkowitej zabudowy [Stelmach-Fita, Wieczorek - wersja cyfrowa].

\section{Ustalenia planu miejscowego - przeznaczenie terenu}

Ustawa o planowaniu i zagospodarowaniu przestrzennym nie definiuje pojęcia przeznaczenie terenu. Rozporządzenie w sprawie wymaganego zakresu projektu miejscowego planu zagospodarowania przestrzennego (rozp. mpzp) ogranicza się do stwierdzenia, że:

1) „ustalenia dotyczące przeznaczenia terenów powinny zawierać określenie przeznaczenia poszczególnych terenów lub zasad ich zagospodarowania, a także symbol literowy i numer wyróżniający go spośród innych terenów” [§ 4. pkt 1 rozp. mpzp];

2) „oznaczenia graficzne i literowe dotyczące przeznaczenia terenów, które należy stosować na projekcie rysunku planu miejscowego, określa załącznik nr 1 do rozporządzenia" [§ 9 ust. 1 rozp. mpzp].

Wyżej wynieniony załącznik nr 1 zawiera listę nazw terenów i ich oznaczeń, np.:

- tereny zabudowy mieszkaniowej jednorodzinnej - symbol MN, kolor jasnobrązowy,

- tereny zabudowy mieszkaniowej wielorodzinnej - symbol MW, kolor ciemnobrązowy,

- tereny zabudowy usługowej - symbol U, kolor czerwony,

- tereny zieleni urządzonej, takie jak: parki, ogrody, zieleń towarzysząca obiektom budowlanym, zieleńce itp. - symbol ZP, kolor zielony,

- cmentarz - symbol ZC, kolor zielony,

- lasy - symbol ZL, kolor ciemnozielony,

- tereny wód powierzchniowych śródlądowych (rzeki, jeziora, stawy, strumienie, kanały) - symbol WS, kolor jasnoniebieski.

Analiza ww. nazw terenów wskazuje, że przeznaczenie terenu/ów należy rozumieć jako informację o tym, jaki rodzaj zabudowy oraz co, prócz zabudowy, może istnieć i powstać na danym terenie, np. rośliny - las, wody. W przeciwieństwie do ustawy o ochronie przyrody, w powyższym załączniku nr 1 wyraźnie oddzielono tereny zieleni urządzonej od cmentarzy.

Powszechnie używane, zarówno w aktach prawa jak i języku potocznym, pojęcie zabudowa nie doczekało się definicji. W rozporządzeniu w sprawie warunków technicznych, jakim powinny odpowiadać budynki i ich usytuowanie (rozp.w.t.) słowo zabudowa nie występuje samodzielnie, a jedynie w zestawieniu z innymi określeniami. Rozporządzenie zawiera definicje pojęć:

1) zabudowa śródmiejska [§ 3 pkt 1 rozp. w.t.];

2) zabudowa jednorodzinna [§ 3 pkt 2 rozp. w.t.];

3) zabudowa zagrodowa [§ 3 pkt 3 rozp. w.t.].

Analiza ww. definicji wskazuje, że poszczególne rodzaje zabudowy to zespoły budynków, a tym samym zespoły obiektów budowlanych i urządzeń budowlanych, bo niewątpliwie budynki, aby mogły funkcjonować, muszą mieć dojazdy i dojścia, wodociągi, kanaliza- 
cję, itp. Z podobnym rozumowaniem, że zabudowa to zespół obiektów budowlanych można się spotkać w obowiązujących planach miejscowych, np.:

1) zabudowa to „budynki i inne obiekty budowlane” [uchwała w sprawie uchwalenia miejscowego planu zagospodarowania przestrzennego w rejonie stacji PKP Siedlce Wschodnie - §2 pkt 13];

2) zabudowa to „obiekty budowlane i urządzenia budowlane, o których mowa w przepisie art. 3 pkt 1 i 9 ustawy z dnia 7 lipca 1994 r. Prawo budowlane” [uchwała w sprawie uchwalenia miejscowego planu zagospodarowania przestrzennego miasta Mińsk Mazowiecki - § 2 pkt 11].

Organ nadzoru nie uznał tak sformułowanych definicji pojęcia zabudowa za istotne naruszenie prawa. Kierując się powyższymi przesłankami można przyjąć, że pojęcie zabudowa oznacza: obiekty budowlane (czyli budynki, budowle i obiekty małej architektury), w tym tymczasowe obiekty budowlane oraz urządzenia budowlane.

Z punktu widzenia kościołów pojęcie przeznaczenie terenu oznacza przede wszystkim, że dany teren jest wyznaczony w planie miejscowym na cel cmentarza wyznaniowego, np. cmentarza katolickiego, cmentarza mariawickiego czy cmentarza Kościoła Ewangelicko-Augsburskiego. Określenie w taki sposób przeznaczenia/celu:

1) pozwala na założenie lub rozszerzenie cmentarza;

2) gwarantuje ww. kościołom, że przeznaczone na cmentarz grunty Skarbu Państwa lub jednostek samorządu terytorialnego będą im oddawane w użytkowanie wieczyste albo sprzedane.

Rozporządzenie w sprawie wymagań, jakie muszą spełniać cmentarze, groby i inne miejsca pochówku zwłok i szczątków ustala szereg wymagań dotyczących cmentarzy, w tym szczegółowe wymiary grobów. Podstawową część cmentarza stanowi powierzchnia grzebalna - miejsce przeznaczone: „na groby ziemne i murowane” oraz „do składania zwłok i szczątków w katakumbach i kolumbariach” [§ 6 rozp.g.c]. Na terenie cmentarza powinno się zapewnić obowiązkowo: „powierzchnię zieleni o charakterze izolacyjnym i dekoracyjnym”, „drogi i ciągi piesze lub pieszo-jezdne”, „miejsca przeznaczone na gromadzenie odpadów”, "punkty czerpalne wody", "teren niezbędny pod kostnicę lub dom przedpogrzebowy" [§ 7 ust. 1 rozp.g.c]. Jeżeli w bezpośrednim sąsiedztwie nie zostały zlokalizowane „place i miejsca postojowe” oraz "ogólnodostępne ustępy”, to powinny się znaleźć na terenie cmentarza [§ 7 ust. 1 rozp.g.c]. W uzasadnionych przypadkach należy również wybudować kaplicę $\mathrm{i}$ „zaplecze administracyjno-gospodarcze” [§ 7 ust. 2 rozp.g.c]. „Cmentarze powinny znajdować się na ogrodzonym terenie" [art. 5 ust. 1 uc], a wysokość ogrodzenia nie powinna być niższa niż 1,5 $\mathrm{m}$ [§ 5 rozp.g.c].

W rozumieniu ustawy Prawo budowlane $(\mathrm{uPb})$ cmentarz jest budowlą. Powyższa ustawa definiuje pojęcie obiekt budowlany - „należy przez to rozumieć budynek, budowlę bądź obiekt małej architektury, wraz z instalacjami zapewniającymi możliwość użytkowania obiektu zgodnie z jego przeznaczeniem, wzniesiony z użyciem wyrobów budowlanych" [art. 3 pkt $1 \mathrm{uPb}$ ]. Ponadto definiuje takie pojęcia jak: budynek [art. 3 pkt $2 \mathrm{uPb}$ ], budowla [art. 3 pkt 3 $\mathrm{uPb}$ ], obiekt małej architektury [art. 3 pkt $4 \mathrm{uPb}$ ] oraz urządzenie budowlane [art. 3 pkt $9 \mathrm{uPb}$ ]. 
Istnieje wyraźna kolizja między przepisami ustawy Prawo budowlane a ww. rozporządzeniem w sprawie wymagań, jakie muszą spełniać cmentarze, groby i inne miejsca pochówku zwłok i szczątków. W świetle przepisów ww. rozporządzenia nie sposób uznać teren, który nazywa się cmentarzem, za budowlę w rozumieniu ustawy Prawo budowlane.

Obydwa te akty prawa są przepisami odrębnymi w rozumieniu przepisu art. 15 ust. 1 ustawy o planowaniu i zagospodarowaniu przestrzennym. Można również zaryzykować twierdzenie, że ww. rozporządzenie jest przepisem odrębnym w stosunku do ustawy Prawo budowlane.

Analiza obiektów, z których składa się cmentarz wskazuje, że:

1) kostnica, dom przedpogrzebowy, kaplica, zaplecze administracyjno-gospodarcze i ustępy to budynki;

2) drogi, ciągi piesze lub pieszo-jezdne i kolumbarium, to budowle;

3) miejsca przeznaczone na gromadzenie odpadów, punkty czerpalne wody, place i miejsca postojowe, to budowle albo urządzenia budowlane;

4) ogrodzenia, to urządzenia budowlane.

Groby ziemne i murowane nie wiadomo jak zakwalifikować. Wydaje się, iż nie można ich uznać za obiekty budowlane w rozumieniu ustawy Prawo budowlane, chociażby dlatego, że ich tworzenie nie wymaga uzyskania decyzji o pozwoleniu na budowę ani zgłoszenia. Nie ma ich również na liście obiektów, które ustawa Prawo budowlane zwalnia z obowiązku uzyskiwania ww. decyzji lub dokonywania ww. zgłoszeń [art. 29, art. 29a i art. 30 uPb]. Tym niemniej są to obiekty wznoszone z użyciem wyrobów budowlanych, a wiec odpowiadają definicji pojęcia obiekt budowlany.

Opierając się na powyższych przepisach można przyjąć, że pod pojęciem przeznaczenie terenu cmentarza rozumie się:

1) wszystkie obiekty, które mogą istnieć i/lub powstać na terenie wyznaczonym na cmentarz, w tym:

a) wszystkie obiekty wymienione w przepisach odrębnych, które muszą albo mogą być na cmentarzu,

b) wybrane obiekty budowlane i urządzenia budowlane w rozumieniu ustawy Prawo budowlane (zabudowa), niezbędne do funkcjonowania cmentarza;

2) ustalenie, czy teren jest przeznaczony na cmentarz komunalny czy na cmentarz wyznaniowy i określenie wyznania.

Przykładowy opis przeznaczenia terenu cmentarza powinien wyglądać następująco: katolicki cmentarz wyznaniowy, w rozumieniu przepisu art. 42 ust. 1 ustawa o stosunku Państwa do Kościoła Katolickiego w Rzeczypospolitej Polskiej, w skład których wchodzą:

1) obiekty wymienione w przepisach $\S 2, \S 5, \S 6$ i $\S 7$ ust. 1 i ust. 2 rozporządzenia w sprawie wymagań, jakie muszą spełniać cmentarze, groby i inne miejsca pochówku zwłok i szczątków (jeśli chce się, aby mogły powstać wszystkie obiekty wymienione w powyższym rozporządzeniu);

2) obiekty budowlane i urządzenia budowlane służące: zaopatrzeniu w wodę, odprowadzaniu ścieków, elektroenergetyce itp., niezbędne do prawidłowego funkcjonowania cmentarza; 
3) wybrane elementy szaty roślinnej (jeśli chce się zachować lub wprowadzić odpowiednie gatunki).

Nie do końca jest jasne, czy ustawa o planowaniu i zagospodarowaniu przestrzennym upoważnia sporządzającego projekt planu miejscowego do określania rodzaju cmentarza komunalny czy wyznaniowy, czyli de facto przez kogo będzie zarządzany i do kogo będzie należał teren nazwany w planie cmentarzem? Załącznik nr 1 do rozporządzenia w sprawie wymaganego zakresu projektu miejscowego planu zagospodarowania przestrzennego, zawiera tylko jedno określenie: cmentarz - symbol ZC. Wydaje się jednak, że przepis art. 15 ust. 1 ustawy o planowaniu i zagospodarowaniu przestrzennym w związku z przepisami odrębnymi, w tym przepisem art. 1 ust. 3 ustawy o cmentarzach i chowaniu zmarłych oraz przepisami ustaw dotyczących stosunku Rzeczypospolitej Polskiej do poszczególnych kościołów daje takie upoważnienie.

Żeby jeszcze bardziej skomplikować ww. problematykę należy zastanowić się jak ustalić przeznaczenie terenu w sytuacji, kiedy istniejący cmentarz komunalny i wyznaniowy leża na terenie otoczonym jednym wspólnym ogrodzeniem i stanowią jedność przestrzenną groby są przemieszane, a władze gminy i kościoła chcą wspólnie powiększyć ww. cmentarze, bez wyodrębniania, który fragment terenu przeznaczonego pod cmentarz w planie miejscowym będzie cmentarzem komunalnym, a który wyznaniowym? Znalezienie odpowiedzi - to temat na odrębny artykut.

\section{Ustalenia planu miejscowego - wybrane zasady kształtowania zabudowy oraz wskaźniki zagospodarowania terenu: intensywność zabudowy, wysokość zabudowy oraz linie zabudowy}

\section{Intensywność zabudowy jako wskaźnik powierzchni całkowitej zabudowy w odniesieniu do powierzchni działki budowlanej}

Ustawa o planowaniu i zagospodarowaniu przestrzennym określa intensywność zabudowy jako wskaźnik powierzchni całkowitej zabudowy w odniesieniu do powierzchni działki budowlanej [art. 15 ust. 2 pkt 6 upzp].

Pojęcie działka budowlana ma trzy różne definicje w obowiązujących przepisach prawa. Czym innym jest działka budowlana w rozumieniu ustawy o planowaniu i zagospodarowaniu przestrzennym niż w rozumieniu ustawy o gospodarce nieruchomościami. Rozporządzenie w sprawie warunków technicznych, jakim powinny odpowiadać budynki i ich usytuowanie zawiera definicję podobną do definicji z ustawy o planowaniu i zagospodarowaniu przestrzennym. Bezspornym jest, że przy sporządzaniu planu miejscowego należy stosować definicję zawartą w ustawie o planowaniu i zagospodarowaniu przestrzennym. Wyżej wymieniona ustawa stanowi, że pod pojęciem działka budowlana należy rozumieć „nieruchomość gruntową lub działkę gruntu, której wielkość, cechy geometryczne, dostęp do drogi publicznej oraz wyposażenie w urządzenia infrastruktury technicznej speł- 
niają wymogi realizacji obiektów budowlanych wynikające z odrębnych przepisów i aktów prawa miejscowego" [art. 2 pkt 2 upzp]. Powyższa definicja nie pozostawia wątpliwości, że intensywność zabudowy należy określić dla każdej działki budowlanej a nie tylko dla działek budowlanych, na których planuje się wybudowanie budynków. Działka budowlana ma spełniać wymogi realizacji obiektów budowlanych, czyli budynków, budowli i obiektów małej architektury.

Jeśli przyjąć, że groby są obiektami budowlanymi, to czy teren cmentarza można uznać za jedną działkę budowlaną?

Jeśli przyjąć, że groby nie są obiektami budowlanymi, to czy teren cmentarza można uznać za szereg działek budowlanych np. przeznaczonych na budowę domu przedpogrzebowego czy kaplicy oraz powierzchnię grzebalną która nie jest działką budowlaną? Ustawa o planowaniu i zagospodarowaniu przestrzennym upoważnia sporządzającego plan miejscowy jedynie do określenia minimalnej powierzchni nowo wydzielonych działek budowlanych [art. 15 ust. 3 pkt 10 upzp], a nie do ich wyznaczana na rysunku planu.

Pojęcia powierzchnia całkowitej zabudowy nie definiuje żadna ustawa, żadne rozporządzenie ani żadna norma. Jest ono różnie definiowane w planach miejscowych, a tym samym ww. plany różnie określają intensywność zabudowy.

W. Parczewski, w swoich podręcznikach, na których wychowało się wiele pokoleń architektów i techników budowlanych, opisuje różne wskaźniki intensywności zabudowy, np.:

1) stosunek sumy powierzchni kondygnacji nadziemnych budynków do powierzchni terenu, [Parczewski 1995, s. 16];

2) stosunek „powierzchni terenów zabudowanych i utwardzonych (dojścia, dojazdy, placyki gospodarcze) do powierzchni terenów zieleni wypoczynkowej i izolacyjnej" [Parczewski 1995, s. 17].

Na podstawie powyższych przesłanek, można przyjąć, że pojecie powierzchnia całkowitej zabudowy to:

- $\quad$ suma powierzchni kondygnacji nadziemnych budynków (przykład 1), albo

- $\quad$ suma powierzchni wszystkich obiektów, które uważa się za zabudowę, w tym suma powierzchni zabudowy, suma powierzchni części budynków nie wliczanych do powierzchni zabudowy oraz suma powierzchni budowli, obiektów małej architektury i urządzeń budowlanych (przykład 2).

W tym miejscu należy wyjaśnić, czym jest powierzchnia zabudowy. Rozporządzenie w sprawie ewidencji gruntów i budynków (rozp. eg) stanowi, że przez pole powierzchni zabudowy „rozumie się pole powierzchni figury geometrycznej określonej przez kontur budynku” [§ 63 pkt 2 rozp. eg]. „Przez kontur budynku (...) rozumie się linię zamkniętą wyznaczoną przez prostokątny rzut na płaszczyznę poziomą linii przecięcia się zewnętrznych ścian budynku z powierzchnią terenu" [§ 63 pkt 1a rozp. eg]. W podobny sposób definiuje to pojecie norma PN-ISO 9836:1997 i norma PN-ISO 9836:2015-12, z tym że definicja z ewidencji gruntów i budynków jest bardziej precyzyjna. Najkrócej mówiąc - to rzut zasadniczej bryły budynku na powierzchnię terenu (bez schodów zewnętrznych, ramp, 
itp.). W żadnym przypadku nie wolno utożsamiać pojęcia powierzchnia zabudowy z pojęciem powierzchnia całkowitej zabudowy. „Do oznaczania jednakowych pojęć używa się jednakowych oznaczeń, a różnych pojęć nie oznacza się tymi samymi określeniami [ $\S 10$ rozp.ztp].

Pojecie powierzchnia całkowitej zabudowy rożnie rozumieją organy nadzoru. Przykładowo, w rozstrzygnięciu nadzorczym Nr LEX-I.4131.48.2017.RM Wojewody Mazowieckiego:

1) uznano za istotne naruszenie prawa definicję opracowaną na podstawie podręcznika W. Parczewskiego (przykład 2);

2) stwierdzono, że definiując „pojęcie powierzchni całkowitej zabudowy, wprowadzono modyfikację pojęcia określonego w art. 15 ust. 2 pkt 6 ustawy o planowaniu i zagospodarowaniem przestrzennym. Przepis ten nie pozostawia wątpliwości, że intensywność zabudowy powinna być określona z uwzględnieniem całkowitej zabudowy. Tym samym stosowany w urbanistyce i budownictwie wskaźnik intensywności zabudowy w przypadku realizacji budynków stanowi stosunek powierzchni całkowitej wszystkich kondygnacji budynków do powierzchni terenu działki budowlanej" [s. 6].

Należy podkreślić, że suma powierzchni całkowitych wszystkich kondygnacji budynku to powierzchnia całkowita budynku w rozumieniu normy PN-ISO 9836:1997 [pkt. 5.1.3.1.] oraz w rozumieniu normy PN-ISO 9836:2015-12 [pkt. 5.1.3.1.]. Organ nadzoru nie powinien narzucać żadnej definicji, a tym bardziej takiej, którą można zinterpretować jako balansującą na granicy prawa. Jak już napisano - różnych pojęć nie oznacza się tymi samymi określeniami [§ 10 rozp.ztp].

Niezależnie od rozważań natury prawnej - definicja pojęcia powierzchnia całkowitej zabudowy - uznana za właściwą w rozstrzygnięciu nadzorczym Nr LEX-I.4131.48.2017.RM nie daje możliwości ustalenia intensywności zabudowy dla terenu całego cmentarza, bo odnosi się do budynków, które zajmują jego marginalną część (kostnica, dom przedpogrzebowy). Możliwość spełnienia wymogu ustalenia intensywności zabudowy na terenie cmentarza dają następujące przesłanki:

1) uznanie, że cały cmentarz jest jedną działką budowlaną;

2) przyjęcie założenia, że groby (bez względu na to, czy traktuje się je jako obiekty budowlane, czy nie) wchodzą w skład pojęcia zabudowa;

3) definicja pojęcia powierzchnia całkowitej zabudowy oparta na założeniu, że w skład tej powierzchni wchodzą położone w całości na terenie i/lub ich części wystające nad powierzchnię terenu obiekty wymienione w rozporządzeniu w sprawie wymagań, jakie muszą spełniać cmentarze, groby i inne miejsca pochówku zwłok i szczątków oraz powierzchnie innych obiektów budowlanych, niezbędnych dla prawidłowego funkcjonowania cmentarza.

Sumując, określanie intensywności zabudowy dla terenu cmentarza jest obarczone dużym ryzykiem - może zostać uznane za istotne naruszenie prawa. Co więcej, wydaje się zbędne, bo w planie miejscowym ustala się obowiązkowo inne wskaźniki rzutujące na intensywność wykorzystania terenu - gabaryty obiektów oraz powierzchnię biologicznie czynną. Bez względu na sposób definiowania pojęcia powierzchnia całkowitej zabudowy i ustalania ile jest działek budowlanych, wyznaczanie intensywności zabudowy jest niezwykle kontrowersyjne i mija się z celem. To przysłowiowa sztuka dla sztuki. 


\section{Wysokość zabudowy}

Ustawa o planowaniu i zagospodarowaniu przestrzennym nie definiuje pojęcia wysokość zabudowy. Definiując to określenie należy brać pod uwagę przesłanki istotne z punktu widzenia kształtowania przestrzenni na danym obszarze oraz odnieść się do definicji pojęcia zabudowa.

Metodę wyznaczania wysokości budynków określa przepis § 6 rozporządzenia w sprawie warunków technicznych, jakim powinny odpowiadać budynki i ich usytuowanie. Wysokość zabudowy można określić jako:

1) wysokość budynków ustaloną metodą przyjętą w powyższym rozporządzeniu;

2) wysokość budowli, obiektów małej architektury, urządzeń budowlanych, wyznaczaną:

a) np. na zasadach przyjętych dla ustalania wysokości budynków,

b) wynikającą z przepisów rozporządzenia w sprawie wymagań, jakie muszą spełniać cmentarze, groby i inne miejsca pochówku zwłok i szczątków, które ustala minimalną wysokość ogrodzenia oraz minimalne wysokości nisz katakumb i kolumbariów.

Jeśli przyjąć, że groby i nagrobki nie są obiektami budowlanymi, to w świetle przyjętego $\mathrm{w}$ niniejszym artykule rozumowania, nie są również elementami zabudowy. Tym samym nie ma delegacji ustawowej do ustalania ich wysokości. Jeśli przyjąć, że groby i nagrobki są obiektami budowlanymi, to wyznaczanie ich wysokości, zwłaszcza na istniejących cmentarzach może wywołać protesty społeczne. Należy pamiętać, że szereg cmentarzy podlega ochronie z mocy ustawy o ochronie zabytków i opiece nad zabytkami. Na takich cmentarzach mechaniczne ustalanie wysokości zabudowy może przynieść więcej szkód niż pożytku.

Bez względu na sposób definiowania pojęcia wysokość zabudowy, jej wyznaczanie na cmentarzach powinno mieć charakter fakultatywny. Niestety, w świetle obecnie obowiązujących przepisów, brak określenia wysokości zabudowy na terenie cmentarza może zostać uznane za istotne naruszenie prawa i doprowadzić do stwierdzenia nieważności uchwalonego planu miejscowego.

\section{Linie zabudowy}

Ustawa o planowaniu i zagospodarowaniu przestrzennym nie definiuje pojęcia linie zabudowy. Za podstawę do opracowania definicji ww. określenia należy przyjąć przesłanki istotne z punktu widzenia kształtowania przestrzenni na danym obszarze oraz definicję pojęcia zabudowa. Przy założeniu, że groby i nagrobki nie są obiektami budowlanymi, a tym samym nie są elementami zabudowy, nie ma delegacji ustawowej do ustalania dla nich linii zabudowy. Przy założeniu, że groby i nagrobki są obiektami budowlanymi brak logicznych przesłanek do wyznaczania tych linii na każdym cmentarzu.

Dla kształtowania przestrzeni najważniejsze jest określenie linii zabudowy budynków przy drogach publicznych i placach. Wyznaczanie linii zabudowy na cmentarzach, zwłaszcza istniejących i podlegających ochronie z mocy ustawy o ochronie zabytków i opiece nad zabytkami, powinno mieć charakter fakultatywny. 
Podobnie jak w przypadku wysokości zabudowy, przy obecnym stanie prawa, brak określenia linii zabudowy na terenie cmentarza może skutkować stwierdzeniem nieważności uchwalonego planu miejscowego.

\section{Podsumowanie}

Na przykładzie cmentarzy wyraźnie widać jak niejednoznaczne są przepisy dotyczące sporządzania miejscowych planów zagospodarowania przestrzennego, a szerzej całych dziedzin prawa związanych z planowaniem przestrzennym, budownictwem, gospodarką nieruchomościami, ochroną zabytków i środowiska. Jednym z podstawowych problemów jest brak definicji kluczowych dla kształtowania przestrzeni pojęć oraz różne definiowanie tych samych określeń w różnych aktach prawa.

Taki stan rzeczy jest różnie oceniany przez osoby związane z problematyką planowania przestrzennego - projektantów, naukowców czy urzędników. Można znaleźć opinie, że formułowane w sposób ogólny przepisy dają władzom gmin swobodę kształtowania przestrzeni, np. poprzez samodzielne definiowanie poszczególnych określeń. „Przepisy nie mogą wszystkich elementów planowania standaryzować tzn. definiować ściśle matematycznie. W planowaniu przestrzennym, zwłaszcza w zakresie ładu przestrzennego, musi być miejsce na uznaniowość, dotyczącą zwłaszcza harmonizacji krajobrazu i architektury obiektów budowlanych. Urbanista sporządzający plany zagospodarowania przestrzennego musi mieć swobodę twórczą w odniesieniu do elementów niepodlegających standaryzacji” [Ney 2012, s. 24].

Potrzebę standaryzacji ustaleń planów miejscowych, a tym samym ograniczenia w mniejszym lub większym stopniu dowolności przy ich sporządzaniu, można uzasadnić następująco:

,--jeśli plany dają jasne i wiążące wskazówki, dalsze postępowanie w kwestii rozbudowy będzie uproszczone i mniej ryzykowne, co pozostawi mniej miejsca na czasochłonne odwołania bądź prywatne lobbowanie władz lokalnych oraz obniży ich częstotliwość;

- daje to właścicielom terenu/inwestorom, sąsiadom, bankom i potencjalnym kupcom większy stopień bezpieczeństwa" [Larsson 2006, s. 62].

To, że ustawa o planowaniu i zagospodarowaniu przestrzennym jest mało precyzyjna, nie określa pojęć kluczowych dla miejscowych planów zagospodarowania przestrzennego, można uznać za świadomy gest ustawodawcy wobec gmin, dający im prawo np. do tworzenia niezbędnych określeń w sposób dostosowany do potrzeb terenu. Takiemu rozumieniu ww. ustawy przeczy postępowanie organów nadzoru, które potrafią stwierdzić nieważność planu miejscowego, uznając za istotne naruszenie prawa opracowanie brakującej definicji, nie bacząc na to, że ich działanie ma negatywne konsekwencje dla gospodarki, może skutkować blokowaniem inwestycji albo doprowadzić do upadku firmę, która jest zatrudniana do wykonania projektu planu miejscowego. „Nie dość, że nie wiadomo jak doprowadzić do zgodności z prawem uchwałę, która prawa nie narusza, to nie ma żadnej gwarancji, że wojewoda nie zakwestionuje po raz kolejny zastosowanych w uchwale definicji" [Stelmach, Wieczorek, wersja cyfrowa, s. 58]. 
Powyższy dylemat pogłębia rozbieżność w postrzeganiu problemu definicji przez różne organy administracji rządowej. Dla byłego Wojewody Mazowieckiego było istotnym naruszeniem prawa sformułowanie definicji pojęcia, które nie jest zdefiniowane w ustawie o planowaniu i zagospodarowaniu przestrzennym. Sekretarz Stanu w byłym już Ministerstwie Inwestycji i Rozwoju miał na ten temat diametralnie inne zdanie. $Z$ odpowiedzi na Interpelację nr 31551 pani poseł Małgorzaty Pępek wynika, że Minister Inwestycji i Rozwoju szanuje władztwo planistyczne gmin, nie popiera powyższych działań wojewodów i dostrzega konieczność zmian prawa. „Wojewodowie nie mogą uznawać za istotne naruszenie prawa sformułowania definicji pojęcia, które nie jest zdefiniowane w ustawie o planowaniu i zagospodarowaniu przestrzennym ani wydanych na jej podstawie przepisach wykonawczych czy przepisach odrębnych powszechnie obowiązujących i stosowanych w planowaniu przestrzennym, skoro nie istnieje jednoznaczne pojęcie, do którego można porównać ocenianą normę prawa. (...) należy stwierdzić, że wojewodowie nie powinni również uznawać za istotne naruszenie prawa odesłania przez sporządzającego plan miejscowy do wybranej przez siebie definicji, o ile dane pojęcie jest definiowane różnie w różnych aktach prawa wyższego rzędu niż plan miejscowy" [Minister Inwestycji i Rozwoju 2019, s. 2].

„Reforma systemu planowania i zagospodarowania przestrzennego ma na celu uproszczenie procesu inwestycyjnego i zwiększenie skuteczności planowania przestrzennego. W przepisach znajdzie się rozbudowany katalog pojęć, który będzie podstawą do tworzenia aktów prawa i decyzji związanych z planowaniem i zagospodarowaniem przestrzennym" [Minister Inwestycji i Rozwoju 2019, s. 3 i 4].

Stanowisko Ministerstwa Inwestycji i Rozwoju napawa optymizmem. Tyle, że tego ministerstwa już nie ma. Oby przedstawiciele obecnego Rządu nie przeczyli sobie wzajemnie, Ministerstwo Rozwoju, któremu obecnie podlega planowanie przestrzenne, doprowadziło do rzeczywistego uproszczenia procesów inwestycyjnych, a wojewodowie szanowali władztwo planistyczne gmin.

Istnieje potrzeba nowelizacji ustawy o planowaniu i zagospodarowaniu przestrzennym oraz szeregu innych ustaw mających wpływ na kształtowanie przestrzeni. O zmianach przepisów powinny decydować m.in. wyniki kompleksowych badań, zakończonych opracowaniem słownika pojęć stosowanych w planowaniu przestrzennym, budownictwie, geodezji, gospodarce nieruchomościami, ochronie środowiska i zabytków, księgach wieczystych oraz systemie podatkowym. Problematyka definiowania określeń stosowanych w aktach prawa oraz konsekwencji wynikających z braku definicji lub różnego definiowania tych samych pojęć nie doczekała się potrzebnych badań. Na początku XXI w. powstał polsko-niemiecki leksykon pojęć planistycznych, w którego opracowaniu brał udział prof. Jan Maciej Chmielewski. Może ww. leksykon mógłby stać się przyczynkiem do dalszych prac nad słownikiem określeń kluczowych dla planowania i gospodarowania przestrzenią.

Stworzenie takiego słownika nie ograniczy władztwa planistycznego gmin. Przeciwnie, ułatwi samorządom sporządzanie planów miejscowych, np. wyeliminuje jeden z powodów stwierdzania ich nieważności. Przyczyni się do tego, że ww. plany będą w sposób bardziej jednoznaczny ustalać, co i na jakich zasadach wolno budować na danym terenie. Zagwaran- 
tuje to właścicielom nieruchomości większy stopień bezpieczeństwa dotyczący dysponowania swoją własnością, a poszukującym odpowiedniego terenu inwestorom ułatwi porównywanie ustaleń planów miejscowych obowiązujących na terenie całej Polski.

\section{Literatura}

Chmielewski J. M., 2001, System planowania przestrzennego w Rzeczpospolitej Polskiej, Polsko-niemiecki leksykon pojęć planistycznych, Hannower-Warszawa.

Długozima A. 2009, Rola cmentarzy w strukturze miast na przykładzie cmentarzy warszawskich [w:] E. Oleksiejuk, A. Jankowska (red.), Zieleń w przestrzeni publicznej miast: funkcja - kreacja - identyfikacja, Toruń.

Długozima A., 2011a, Cmentarze obrazem kondycji społeczności. Badanie cmentarzy dla odtworzenia kultury społeczności lokalnych [w:] A. Zglińska, P. Pranke (red.), Pamiętać czy zapomnieć? Miejsca pamięci we wspótczesnym dyskursie naukowym, Teka Historyka.

Długozima A., 2011b, Szata roślinna cmentarzy [w:] M. Drozdek, (red.), Rośliny do zadań specjalnych. Zieleń Miast i Wsi wspótczesna i zabytkowa, Oficyna Wydawnicza PWSZ w Sulechowie, Sulechów.

Grodzka K., 1988, Założenie i historia cmentarza Rakowickiego [w:] Ł. Klimas, E. Czałkowska (red.), Cmentarz Rakowicki w Krakowie, Agencja OMNIPRESS, Warszawa, s. 7-19.

Krawczuk A., 1988, ...To miasto umarłych, ta dolina łez i śmierci, to najpiękniejsza przeszłość Krakowa... [w:] Ł. Klimas, E. Czałkowska (red.), Cmentarz Rakowicki w Krakowie, Agencja OMNIPRESS, Warszawa, s. 3-6.

Krupa B., 2013, Administracyjnoprawne uwarunkowania inwestycji celu publicznego, Difin SA, Warszawa.

Larsson G., 2006, Systemy planowania przestrzennego w Europie Zachodniej, ISO Press, The Netherlands, 2006 r.; przekład na język polski T. Śliwowski, Mazowiecka Okręgowa Izba Architektów RP, Warszawa.

Ney B. 2012, Ocena systemu planowania przestrzennego w Polsce oraz sugestie jego poprawy [w:] A. Maciejewska (red.) Gospodarka przestrzenna w świetle wymagań strategii zrównoważonego rozwoju, Komitet Przestrzennego Zagospodarowania Kraju PAN, Warszawa, s. 22-26.

Parczewski W., 1995, Dokumentacja budowlana 4. Projektowanie architektoniczne, Wydawnictwa Szkolne i Pedagogiczne, wydanie czwarte, Warszawa.

Stelmach-Fita B. Wieczorek A. Problemy z ocenianiem zgodności z prawem miejscowych planów zagospodarowania przestrzennego: definicje pojeć powierzchnia zabudowy i powierzchnia całkowitej zabudowy, Metropolitan Przegląd Naukowy, 1, 11. Półrocznik publikowany w formie cyfrowej ISSN 2353-7558, s. 50-59. 


\section{Materiały źródłowe}

\section{Źródła prawa}

Konstytucja Rzeczypospolitej Polskiej z dnia 2 kwietnia 1997 r. (Dz.U.nr 78, poz. 483 z późn. zm.).

\section{Ustawy}

Ustawa z dnia 17 marca 1932 r. o chowaniu zmarłych i stwierdzaniu przyczyny zgonu (Dz.U. poz. 359, z późn. zm.), w skrócie uchz. Ustawa nie obowiązuje.

Ustawa z dnia 31 stycznia 1959 r. o cmentarzach i chowaniu zmarłych, (tj. z dnia 11 czerwca 2019 r. Dz.U. z 2019 r. poz. 1473), w skrócie uc.

Ustawa z dnia 17 maja 1989 r. o stosunku Państwa do Kościoła Katolickiego w Rzeczypospolitej Polskiej (tj. z dnia 28 czerwca 2019 r. Dz.U. z 2019 r. poz. 1347), w skrócie usPKK.

Ustawa z dnia 13 maja 1994 r. o stosunku Państwa do Kościoła Ewangelicko-Augsburskiego w Rzeczypospolitej Polskie (tj. z dnia 16 grudnia 2014 r. Dz.U. z 2015 r. poz. 43), w skrócie usPKEA.

Ustawa z dnia 7 lipca 1994 r. Prawo budowlane (tj. z dnia 21 maja 2019 r. Dz.U. z 2019 r. poz. 1186, z późn. zm.), w skrócie uPb.

Ustawa z dnia 20 lutego 1997 r. o stosunku Państwa do Kościoła Katolickiego Mariawitów w Rzeczypospolitej Polskiej (tj. z dnia 12 grudnia 2014 r. Dz.U. z 2015 r. poz. 44), w skrócie usPKM.

Ustawa z dnia 21 sierpnia 1997 r. o gospodarce nieruchomościami (tj. z dnia 25 października 2018 r. Dz.U. z 2018 r. poz. 2204, z późn. zm.), w skrócie ugn.

Ustawa z dnia 27 marca 2003 r. o planowaniu i zagospodarowaniu przestrzennym, (tj. z dnia 14 września 2018 r. Dz.U. z 2018 r. poz. 1945, z późn. zm.), w skrócie upzp.

Ustawa z dnia 23 lipca 2003 r. o ochronie zabytków i opiece nad zabytkami (tj. z dnia 3 października 2018 r. Dz.U. z 2018 r. poz. 2067, z późn. zm.), w skrócie uz.

Ustawa z dnia 16 kwietnia 2004 r. o ochronie przyrody (tj. z dnia 20 lipca 2018 r. Dz.U. z 2018 r. poz. 1614, z późn. zm.), w skrócie up.

\section{Rozporządzenia}

Rozporządzenie Ministra Gospodarki Komunalnej z dnia 25 sierpnia 1959 r. w sprawie określenia, jakie tereny pod względem sanitarnym są odpowiednie na cmentarze (Dz.U. nr 52, poz. 315), w skrócie rozp.san.c. 
Rozporządzenie Ministra Rozwoju Regionalnego i Budownictwa z dnia 29 marca 2001 r. w sprawie ewidencji gruntów i budynków (tj. z dnia 13 stycznia 2019 r. Dz.U. z 2019 r. poz. 393) , w skrócie rozp. eg.

Rozporządzenie Ministra Infrastruktury z dnia 12 kwietnia 2002 r. w sprawie warunków technicznych jakim powinny odpowiadać budynki i ich usytuowanie, (tj. z 8 kwietnia 2019 r. Dz.U. z 2019 r. poz. 1065), w skrócie rozp.w.t.

Rozporządzenie Prezesa Rady Ministrów z dnia 20 czerwca 2002 r. w sprawie „Zasad techniki prawodawczej” (tj. z dnia 29 lutego 2016 r. Dz.U. z 2016 r. poz. 283, z późn. zm.) w skrócie rozp.ztp.

Rozporządzenie Ministra Infrastruktury z dnia 26 sierpnia 2003 r. w sprawie wymaganego zakresu projektu miejscowego planu zagospodarowania przestrzennego (Dz.U. nr 164, poz. 1587), w skrócie rozp. mpzp.

Rozporządzenie Ministra Infrastruktury z dnia 7 marca 2008 r. w sprawie wymagań, jakie muszą spełniać cmentarze, groby i inne miejsca pochówku zwłok i szczątków (Dz.U. nr 48, poz. 284), w skrócie rozp. g.c.

\section{Akty prawa miejscowego}

Uchwała nr LII/584/2018 Rady Miasta Siedlce z dnia 25 czerwca 2018 r. w sprawie uchwalenia miejscowego planu zagospodarowania przestrzennego $\mathrm{w}$ rejonie stacji PKP Siedlce Wschodnie, (Dz.Urz. Woj. Mazowieckiego z 18 lipca 2018 r. poz. 7289).

Uchwała nr XLV.442.2018 Rady Miasta Mińsk Mazowiecki z dnia 15 października 2018 r. w sprawie uchwalenia miejscowego planu zagospodarowania przestrzennego miasta Mińsk Mazowiecki (Dz.Urz. Woj. Mazowieckiego z 19 października 2018 r. poz. 9935).

\section{Normy}

Norma PN-ISO 9836: 1997, Polski Komitet Normalizacji 1997 r. (norma wycofana w rozumieniu Polskiego Komitetu Normalizacji).

Norma PN-ISO 9836: 2015-12, Polski Komitet Normalizacji 2015 r. (norma aktualna w rozumieniu Polskiego Komitetu Normalizacji).

\section{Dokumenty}

Rozstrzygnięcie nadzorcze Nr LEX-I.4131.48.2017.RM Wojewody Mazowieckiego z dnia 8 marca 2017 r., dotyczy uchwały Nr XXV.237.2017 Rady Miasta Mińsk Mazowiecki z dnia 30 stycznia 2017 r. „w sprawie uchwalenia miejscowego planu zagospodarowania przestrzennego miasta Mińsk Mazowiecki” (Dz.Urz. Woj. Mazowieckiego z 15 marca 2017 r. poz. 2549). 
Interpelacja nr 31551 do ministra inwestycji i rozwoju w sprawie definiowania pojęć, które należy określić w miejscowych planach zagospodarowania przestrzennego. Zgłaszający: Małgorzata Pępek. Data wpływu: 20 maja 2019 r., w skrócie interpelacja nr 31551.

Minister Inwestycji i Rozwoju, 9 lipca 2019 r., znak sprawy: DPR-II.053.16.2019. Dotyczy: odpowiedzi na interpelację nr 31551 Pani Poseł Małgorzaty Pępek w sprawie definiowania pojęć, które należy określić w miejscowych planach zagospodarowania przestrzennego.

\section{A cemetery in a local spatial development plan}

\section{ABSTRACT}

The article discusses selected issues related to the introduction of cemeteries into local spatial development plans. In particular, it recommends the following:

1) precisely defining the term "land use";

2) eliminating the obligation to determine the density of housing development;

3) introducing the regulation that determining the height and building alignment is optional.

By using a cemetery as an example, the article indicates the lack of precision in provisions regarding planning and space management. This is due to a lack of crucial definitions and a different understanding of the same concepts within particular acts of law. The article describes procedures used for implementing certain arrangements as required by the Spatial Planning and Management Act. It does not define the concepts obligatory for implementation of the above-mentioned arrangements, though. The paper stresses that the procedures outlined above are not always respected by the regulatory authorities. This may result in a cancellation of local spatial development plans. Based on surveyed records, the paper demonstrates how the aforementioned issues are addressed by lawmakers.

To sum up, the paper:

1) justifies the need for the development of a coherent glossary of terms used in spatial planning, construction, geodesy, real estate management, environmental and monument protection, land and mortgage registers and the tax system. Such a glossary could then be used to amend particular legal acts;

2) demands that the regulatory authorities respect the „municipalities” planning jurisdiction.

Key words: cemetery, local spatial development plan, public purpose, acts, definitions

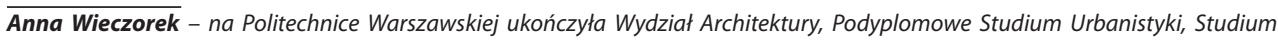
Doskonalenia Pedagogicznego oraz uzyskała dyplom doktora nauk technicznych. Posiada uprawnienia do projektowania w planowaniu przestrzennym oraz uprawnienia do pełnienia samodzielnych funkcji technicznych w budownictwie. Specjalizuje się w wykonywaniu projektów miejscowych planów zagospodarowania przestrzennego (główny projektant ponad 30 uchwalonych projektów planów miejscowych) oraz projektów studiów uwarunkowań i kierunków zagospodarowania przestrzennego gmin (główny projektant 5 uchwalonych stdiów). Ma doświadczenie w pracy ze studentami - na Politechnice Warszawskiej i w Wyższej Szkole Przedsiębiorczości i Administracji w Lublinie. Należy do Mazowieckiej Okręgowej lzby Architektów z siedzibą w Warszawie oraz Pan-Europejskiej Federacji Ochrony Zabytków - Europa Nostra z siedzibq̨ w Holandii.
} 


\section{CMENTARZ W MIEJSCOWYM PLANIE ZAGOSPODAROWANIA PRZESTRZENNEGO \\ Anna Wieczorek}

Anna Wieczorek - graduated from Warsaw University of Technology - Faculty of Architecture, Postgraduate Town Planning Studies, Pedagogical study, PhD in technical science. She holds professional permits for spatial planning and is authorized to perform independent technical functions in construction. She specializes in the execution of local spatial development plans (the main designer of more than 30 approved local development plans) and of the studies of conditions and directions of the spatial development of municipalities (main designer of 5 approved studies). She has experience in working with students - at the Warsaw University of Technology and the University College of Enterprise and Administration in Lublin. She belongs to Warsaw-based Masovian Chamber of Architects and the Pan-European Federation for Cultural Heritage, Europa Nostra based in the Netherlands. 